\title{
KIBRIS TEREKE KAYITLARINDA KÖLELER (17. VE 18. YY.)
}

\author{
Dr.Öğr.Üyesi Ümit GÜLER \\ Batman Üniversitesi İslami lilimler Fakültesi
}

\section{ÖZ}

Tarihî, hukukî, iktisadî ve sosyolojik boyutlarıyla kölelik, tarihin derinliklerinden 20. yüzyılın sonlarına kadar süregelen, insanlığın en eski kurumlarından biridir. Osmanlı'nın da kendinden önceki devletlerden devraldığı bu kadim müesseseye dair, arşiv belgelerinde oldukça kıymetli bilgiler mahfuzdur. Bu mevzuda zengin malumat sağlayacak arşiv kaynaklarından biri de şüphesiz tereke kayıtlarıdır. Müslümanların farklı zaman ve yerlerdeki tarihsel tecrübelerinin hakikate muvafık biçimde gün yüzüne çıkarılabilmesi için bu belgelerin tetkik edilmesi elzemdir. Zira Osmanlı Kıbrısı'ndaki kölelik kurumu da adanın sosyal tarihinin aydınlatılmayı bekleyen bakir alanlarından biridir. Binaenaleyh bu çalışmada 17. ve 18. (H. 12-13) yüzyıl Kıbrıs tereke kayıtları incelemeye tabi tutularak bu dönemdeki kölelere ve köle sahibi olan kişilere odaklanılmıştır. Bilhassa terekelerde yer alan kölelerin sayısı, cinsiyeti, ırkı ve değeri gibi birçok hususta aydınlatıcı bilgiler edinilmiştir. Çalışmanın veri tabanını, ilgili dönem Kıbrıs'ına ait tüm tereke kayıtları oluşturmaktadır.

Anahtar Kelimeler: Osmanlı Kıbrısı, Kölelik, Kıbrıs, Tereke Kayıtları, Kadı Sicilleri

\section{ABSTRACT}

Slaves in Cyprus Inheritance Records (17th and 18th Centuries)

With its historical, legal, economic and sociological dimensions, slavery is one of the oldest institutions of mankind, from the depths of history to the end of the 20th century. The valuable information about this great institution, which the Ottomans inherited from the previous states, is preserved in archive documents. One of the sources of archive that will provide rich information in this regard is undoubtedly inheritance records. It is important to examine these documents to provide true historical experiences that Muslims have in different times and places. Because, the slavery institution in Ottoman Cyprus is one of the pristine areas waiting for the social history of the island to be illuminated. For this reason, in this study, the 17th and 18th century Cyprus inheritance records were examined and focused on slave and slave owners in that period. In particular, enlightening information on a number of subjects such as the number of slaves, gender, race, and values were acquired in the inheritances. All heritage records belonging to Cyprus of that period constitute database of this study.

Keywords: Art of Ottoman Bookbinding, Medallion, Cloud Motif, Free Cloud Ribbon Motif, Dragon. 


\section{Giriş}

Bilindiği üzere köle, başkasının mülkiyetinde bulunarak hürriyetten yoksun olan ve dolayısıyla alınıp satılabilen insanlardır. ${ }^{1}$ Aralarında hukukî bakımdan herhangi bir farklılık bulunmamakla beraber² Osmanlı'da bunların erkek olanlarına kul, abd veya köle; kadın ve kızlara da câriye, memlûke veya odalık gibi muhtelif isimler verilirdi. ${ }^{3}$ incelediğimiz Kıbrıs tereke kayıtlarında ise erkekler için köle, gulam, ${ }^{4}$ arab ve abd tabirlerinin kullanıldığı gözlenmiştir. Kadın ve kız köleler de câriye olarak ifade edilmiştir.

İnsanlık tarihi kadar eskilere giden kölelik olgusu, İslam'ın doğduğu dönemde dünya genelinde olduğu gibi Arap yarımadasında da toplumun sosyal ve ekonomik yapısına derinlemesine nüfuz etmiş bir durumdaydı. ${ }^{5} \mathrm{Bu}$ kökleşmiş vaziyet karşısında Kur'ân, kölelik müessesesini belli bir çerçevede kabullenmiş olsa da onu ortadan kaldıracak etkili tedbirler alma yoluna gitmiştir. ${ }^{6}$ Kur'ân'ın köleliği sona erdirmeye matuf yaklaşımlarının yanı sıra İslam'ın pratik boyutunu yansıtan Hz. Peygamber'in uygulamaları da bunun açık bir göstergesi olmuştur. $^{7} \mathrm{~Hz}$. Peygamber'den sonra gelen Hulefa-yı Raşidin döneminde kölelerin insanî ve hukukî durumlarında meydana gelen köklü iyileşmelerin devam ettirildiği;: fakat Emevilerle birlikte bu sürecin kesintiye uğradığı ifade edilir. ${ }^{9}$ Bunun yanı sıra İslam tarihi boyunca Müslüman toplumlarda köle âzadının belli oranda devam ettirildiği gözlenmekle birlikte, ${ }^{10}$ kölelik müessesesi üzerine saygın çaısşmaları bulunan bizzat Batılı araştırmacılar tarafından da köleliğin İslam dün-

1 Pakalın, Mehmet Zeki, Osmanlı Tarih Deyimleri ve Terimleri Sözlüğü, Milli Eğitim Basımevi, İstanbul, 1983, II, 300. Ayrıca bkz. Pakalın, Osmanlı Tarih Deyimleri ve Terimleri Sözlügü, I, 259; Bilmen, Ömer Nasuhi, Hukukı İslâmiyye ve Istılahatı Fıkhıyye Kamusu, Bilmen Yayınevi, İstanbul ty., III, 332.

2 Akgündüz, Ahmed, İslâm Hukukunda Kölelik-Câriyelik Müessesesi ve Osmanlı'da Harem, Osmanlı Araştırmaları Vakfı, İstanbul, 2006, s. 120; Bu çalıșmada köle tabiri ile her iki cinsiyet kastedilmektedir. Cinsiyet belirtilmesinin uygun görüldüğü yerlerde erkekler için köle, kadın ve kızlar için de câriye kelimeleri kullanılacaktır.

3 Osmanlı'da köleleri ifade etmek üzere birçok tabir kullanılmıştır. Bunlar başlıca şöyledir: Erkekler için köle, esir, kul, bende, halayık, abd, rakik, memlûk, kınn, gulâm, rakabe, vasîf, milkü'l-yemîn ve gulamdır. Kadın köleler için ise câriye, odalık, memlûke, vasîfe, eme, gurre ve kenîzdir. bkz. Hamîdullah Muhammed-Aydın, Mehmet Âkif, "Köle", Türkiye Diyanet Vakfı i̇slâm Ansiklopedisi (DiA), XXVI, 237.

4 Büluğa ermiş genç çocuk anlamına gelir. bkz. Sertoğlu, Midhat, Osmanlı Tarih Lügatı, Kurtuba Kitap, İstanbul, 2015, s. 196.

5 Özdemir, Mehmet Nadir, İslam'ın IIlk Döneminde Kölelik Abbasilerin IIlk Yüzyılı, Gökkubbe Yay., İstanbul, 2006, s. 26-29.

${ }^{6}$ Hatalmış, Ali, Erken Dönem İslam Tarihinde Kölelik ve Câriyelik (Hz. Peygamber Döneminden Emevîlerin Sonuna Kadar), Basılmamıs Doktora Tezi, Ankara Üniversitesi Sosyal Bilimler Enstitüsü, Ankara, 2012, s. 34.

7 Geniș bilgi için bkz. Alvân, Abdullah Nâsıh, Nizâmu'r-rıq fi'l-İslâm, Dâru's-selâm, yk. 2004, s. 29-35

8 Hatalmış, İslam Tarihinde Kölelik ve Câriyelik, s. 95. Benzer bir değerlendirme için bkz. Lewis, Bernard, Ortadoğu'da Irk ve Kölelik, Truva Yayınları, Çev. Enver Günsel, İstanbul, 2006, s. 15-16.

9 Câhız, Ebû Osman Amr b. Bahr, el-Beyân ve't-tebyîn, Neşr. Muhammed Harûn Abdüsselam, Kahire, 1418/1997, II, 335-337; bkz. Harekât, İbrahim, es-Siyâsetu ve'l-mucteme 'u fi'l- asri'l-Emevî, Rabat 1410/1990, s. 218; Hatalmış, İslam Tarihinde Kölelik ve Câriyelik, s. 104; Özdemir, İslam'ın İlk Döneminde Kölelik, s. $37 \mathrm{vd.}$

10 Alvân, Nizâmu'r-rıq, s. 50; Hamîdullah-Aydın, “Köle”, DiA, XXVI, 242. 
yasında ve bilhassa Osmanlı'da Batı'ya nazaran çok daha insanî bir boyutta tecrübe edildiği de ifade edilmiştir. ${ }^{11}$

Çalışmamızın veri tabanını 17. ve 18. (H. 12-13) yüzyıla ait mevcut Kıbrıs kadı sicillerinin tamamı olan 22 defter ve bunların içerisinde karışık vaziyette yer alan "tereke kayıtları" oluşturmaktadır. ${ }^{12}$ Kıbrıs tereke kayıtlarında köleler mevzuuna geçmeden önce Osmanlı'daki tereke kayıtlarına ana hatlarıyla değinmekte fayda vardır.

Tereke, muhallefât veya metrûkât kavramları, ölen kişinin mal varlığını ifade etmek üzere literatürde birbirlerinin yerine kullanılabilen tabirlerdir. ${ }^{13}$ Osmanlı hukuk sisteminde vefat eden kişilerin geride bıraktıkları eşya ve mallarının tespit ve taksimini başlangıçta kadılar gerçekleştirmiş olup bu görev zamanla kadıların maiyetindeki kassâm denilen memurlara tevdi edilmişti. ${ }^{14}$ Şayet ilgili kadııkta kassâm yoksa bu işi bizzat kadılar görürdü. ${ }^{15}$ Mirasçısı bulunmayan veya belli olmayan ölülerin ya da senelerdir kayıplara karışan şahısIarın mirasları bu kimselerce tespit edilerek tereke kaydı oluşturulurdu. ${ }^{16}$ Ancak askerî zümreye mensup kişilerin terekelerinin kayıt altına alınması zorunlu olsa da sivil kesimin miras taksimini kadıya yaptırma gibi bir zorunluluğu yoktu. Kadının miras taksimine müdahale etmesi, ancak mirasçıların veya alacaklıların talebi doğrultusunda yahut mirasçılar arasında mecnun veya çocukların bulunması gibi birtakım özel durumlarda söz konusu olurdu. ${ }^{17}$

Sivil halkın miras taksimi için kadıya gitme zorunluluğunun olmamasının yanı sıra kadılık makamınca terekenin kaydedilmesi esnasında "resm-i kısmet" adı altında bir verginin alınması da mahkemeye müracaatı büyük ölçüde engellediği düşünülmektedir. ${ }^{18}$ Dolayısıyla incelenen sicillerdeki tereke defterleri, ilgili döneme ait tüm terekeleri içermediği gibi oran olarak da ne kadarını içerdiğine dair herhangi bir tahmin yürütülemez. ${ }^{19} \mathrm{Hal}$ böyleyken araştırmamızda elde edilen tereke kayıtlarının, sicillerin ait oldukları dönemde yaşamış “bazı kişile-

\footnotetext{
11 Lewis, Irk ve Kölelik, s. 17, 171; Toledano, Ehud R., Osmanlı Köle Ticareti 1840-1890, Tarih Vakfı Yurt Yayınları, İstanbul, 2000, s. 4.

12 Çalışmamız kadı sicillerindeki tereke ile ilgili intilaflara veya tereke davalarına değil, kendine özgü bir hususiyet arz eden "tereke kayıtlarına" odaklanmıştır.

13 Bozkurt, Fatih, "Osmanlı Dönemi Tereke Defterleri ve Tereke Çalışmaları", Türkiye Araştırmaları Literatür Dergisi, 11/22, (2013): 193; Özcan, Tahsin, “Muhallefât”, DiA, XXX, 406.

14 Özcan, "Muhallefât", DiA, XXX, 406.

15 Aydın, M. Âkif, Türk Hukuk Tarihi, 5. Baskı, Hars Yay., İstanbul, 2005, s. 90; Ekinci, Ekrem Buğra, Osmanlı Hukuku, Arı Sanat Yay., İstanbul, 2008, s. 377.

16 Sabev, Orlin, “Osmanlı Toplumsal Tarihi İçin Değerli Kaynak Teşkil Eden Tereke ve Muhallefat Kayıtları", Osmanlı Coğrafyası Kültürel Arşiv Mirasının Yönetimi ve Tapu Arşivlerinin Rolü Uluslararası Kongresi, Bildiriler, I, 21-23 Kasım 2012, İstanbul, s. 265.

17 Özcan, "Muhallefât", DiA, XXX, 406.

18 Karataş, Ali İhsan, “Tereke Kayıtlarına Göre XVI. Yüzyılda Bursa'da İnsan-Kitap iliş̧kisi”, Uludağ Üniversitesi İlahiyat Fakültesi Dergisi, 8/8, (1999): 318; İnalcık, Halil, “XVI. Asır Türkiye'nin İktisadî ve İctimaî Kaynakları", İstanbul Üniversitesi Iktisat Fakültesi Mecmuası, 15/1-4, (1954): 51.

19 Sabev, "Tereke ve Muhallefat Kayıtları", s. 264.
} 
rin" geride bıraktıkları mal ve eşyalarını gösteren belgeler olduğu izahtan varestedir.

Tereke kayıtları, genellikle Osmanlı mahkemelerinde verilen kararların ve tutulan kayıtların yer aldığı defterler olan şer'iyye sicilleri içerisinde bulunurlar. Zira düşük nüfusa sahip kaza kadılıkları başta olmak üzere, çoğu Osmanlı şehrine ait tereke defterleri şer'iyye sicil defterlerinin içerisinde karışık halde yer alır. Nitekim ilgili dönem Kıbrıs sicillerinde de durum böyledir. İstanbul gibi mevleviyet statüsündeki yüksek dereceli kadılıklarda ise tereke defterleri ve mirasla ilgili diğer evraklar, müstakil siciller olarak tanzim edilmişlerdir. ${ }^{20}$

Ölen kişilerin geride bıraktıkları her türlü menkul ve gayrimenkul malların detaylı listesini ve tereke toplamından çeşitli masraf ve harcamalar düşüldükten sonra kalan malların mirasçılar arasında İslam miras hukukuna göre taksimini içeren tereke defterleri, bilhassa sosyal tarih araştırmaları için ciddi bir önemi haizdir. ${ }^{21}$ Zira söz konusu tereke kayıtları vefat edenlerin sosyal statüsü, mesleği, maddî durumu, aile yapısı, sosyal ve devlet-kişi ilişkileri hakkında zengin malumat sağlamakta olup, Osmanlı sosyo-ekonomik tarihi hakkında önemli bir kaynak teşkil etmektedir. ${ }^{22}$ Giriş kısmında temas edildiği gibi tarihsel açıdan genel olarak İslam, özel olarak da Osmanlı toplumunun önemli bir unsuru da kölelerdir ve bu çalışmada Kıbrıs tereke kayıtlarında yer alan köleler ilk kez inceleme konusu edilerek bu cihetten Osmanlı Kıbrısı'nın sosyal tarihine ışık tutulmaya çalışıımıştır.

\section{Kıbrıs Tereke Kayıtlarında Köleler}

Kadı sicillerinde yer alan tereke kayıtları Osmanlı Kıbrısı'ndaki kölelere dair önemli bilgiler içermektedir. Bu kayıtlardan terekelerde yer alan kölelerin sayıSı, cinsiyeti, ırkı ve değeri gibi birçok hususta bilgi edinilebilmektedir. Araştırma dönemimiz olan 17. ve 18. (H. 12-13) yüzyıla ait Kıbrıs kadı sicil defterleri üzerinde yaptığımız incelemede 287 adet tereke kaydı ${ }^{23}$ tespit edilmiş ve bunların sadece 39 adedinde köle yer almıştır. Bu da döneme ait tüm tereke kayıtlarının sadece \%13.58'inde köle bulunduğu anlamına gelmektedir. Bu durum toplumda ancak sınırlı bir kesimin köle sahibi olduğuna dair önemli bir göstergedir. Hatta mahkemeye intikal eden veya ettirilen tereke kayıtlarının niteliği ve mal varlığının genel düzeyi göz önünde bulundurulursa, bu oranın gerçekte çok daha düşük olduğu düşünülebilir. Zira ilgili dönem tereke kayıtlarına bakıldığında

\footnotetext{
20 Bozkurt, "Tereke Defterleri ve Tereke Çalışmaları", s. 193.

${ }^{21}$ Bozkurt, "Tereke Defterleri ve Tereke Çalışmaları", s. 94; İnalcık, "iktisadî ve Iç̧timaî Tarihi Kaynaklar", s. 51-73.

22 Sabev, "Tereke ve Muhallefat Kayıtları", s. 260; İnalcık, Halil, "Osmanlı Tarihi Hakkında Mühim Bir Kaynak", Ankara Üniversitesi Dil ve Tarih-Coğrafya Fakültesi Dergisi, 1/1, (1943): 89-96.

${ }^{23} \mathrm{Bu}$ tereke kayıtları mirasçılara intikal eden malları gösterdiği gibi mirasçısı olmadığı için beytülmâle kalan tereke kayıtlarını da içermektedir.
} 
terekelerin genelde varlıklı insanlara ait oldukları dikkati çekmektedir. Dolayısıyla fakir insanların terekeleri zenginlerinki kadar sicillere yansımamıştır. Nitekim Osmanlı'da tereke kayıtlarının genelde varlıkı insanların ölümünün ardından bu kimselerin mallarını tespit ve taksim etmek için yapıldığı ifade edilir. Çünkü bu gibi durumlarda mirasçılar arasında malların paylaştırılması hususunda yaşanabilecek intilaflar daha muhtemel telakki edilir. ${ }^{24}$ Dolayısıyla orta halli veya en azından fakir denebilecek kimselerin terekelerinin zenginler kadar mahkeme kayıtlarına yansımamış olması tabiî bir neticedir. Bunun yanı sıra az varlıklı kişilerin terekelerinden tahsil edilen "resm-i kısmetin”, yani tereke düzenleme ücretinin nisbî oranının daha varlıklı ölülerin terekelerinden tahsil edilen ücretlere nazaran daha yüksek olduğu belirtilmekte; 25 bu ücreti vermemek için de fakir ve orta halli mirasçıların taksimat amacıyla mahkemeye müracaattan içtinap ettikleri tahmin edilmektedir. ${ }^{26}$ Ancak şu da ifade edilmelidir ki döneme ait birçok tereke kaydı için böyle bir ayrım söz konusu değildir. Zira ölen kişinin mal varlığı az veya çok olsun, mirasçısının bulunmadığı durumlarda geride bıraktığı malı mahkemece açık artırma usulüyle satılmış ve geliri devlet hazinesine (beytülmâl) intikal ettirilmiştir.

Söz konusu terekelerde geçen 65 köleye cinsiyetleri açısından bakıldığında 35 erkek, 30 da kadın köle (câriye) olmak üzere dengeli bir dağılımın olduğu görülür. ${ }^{27}$ Erkek ve kadın kölelerin ezici çoğunluğu da siyahîdir. Zira 65 adet köIenin 49'u siyahî olup, 8'i beyazdır. Geriye kalan 8 kölenin de ırkından veya renginden bahsedilmemiştir. Dolayısıyla incelenen belgeler, terekelerde zikredilen kölelerin en az \%75.38'inin siyahî olduğunu göstermektedir. Siyahî kölelerin kendi içlerindeki cinsiyet dağılımına bakıldığında 49 adet siyahî kölenin 27 'sinin erkek, 22'sinin ise kadın (câriye) olduğu görülür. 8 adet olan beyaz kölelerin de 5'i kadın olup 3'ü erkektir. 8 adet beyaz köle içerisinde milliyet bakımından 4 câriyenin 2'sinin Gürcü, 2'sinin Mısırlı, 1 erkek kölenin de Acem olduğu ifade edilmiştir. Irkından veya renginden bahsedilmeyen 8 kölenin de 5'i erkek olup 3'ü kadındır. Bu bilgiler aşağıdaki tabloda gösterilmiştir.

Tablo:1

\begin{tabular}{|l|l|l|l|l|l|l|l|l|}
\hline Köle Sayısı & 65 & & & & & & & \\
\hline Cinsiyet & Erkek & 35 & Kadın & 30 & Toplam & 65 & & \\
\hline
\end{tabular}

${ }^{24}$ Sabev, "Tereke ve Muhallefat Kayıtları", s. 260.

25 Ergene, Boğaç A., "Costs of Court Usage in Seventeenth and Eighteenth Century Ottoman Anatolia: Court Fees as Recorded in Estate Inventories", Journal of the Economic and Social History of the Orient, 45/1, (2002): 20-39.

26 İnalcık, "Iiktisadî ve İçtimaî Tarihi Kaynaklar”, s. 54; Ergene, “Costs of Court Usage”, s. 20-39.

27 Köle sayısı tespit edilirken ilgili tereke kayıtlarındaki tüm yaş grupları dikkate alınmıştır. Örneğin kimi kayıtlarda câriye olan anneyle beraber küçük çocuğu da zikredilmektedir. Bu durumda iki ayrı köle olarak hesaplama yapılmıştır. 


\begin{tabular}{|c|c|c|c|c|c|c|c|c|}
\hline Irk & Siyahî & 49 & Beyaz & 8 & Belirsiz & 8 & Toplam & 65 \\
\hline $\begin{array}{l}\text { Siyahî Köle- } \\
\text { lerin Cinsi- } \\
\text { yet Dağılımı }\end{array}$ & Erkek & 27 & Kadın & 22 & Toplam & 49 & & \\
\hline $\begin{array}{l}\text { Beyaz Köle- } \\
\text { lerin Cinsi- } \\
\text { yet Dağılımı }\end{array}$ & Erkek & 3 & Kadın & 5 & Toplam & 8 & & \\
\hline $\begin{array}{l}\text { Irkı Belirsiz } \\
\text { Kölelerin } \\
\text { Cinsiyet } \\
\text { Dağılımı }\end{array}$ & Erkek & 5 & Kadın & 3 & Toplam & 8 & & \\
\hline $\begin{array}{l}\text { Beyaz Köle- } \\
\text { lerin Milli- } \\
\text { yet Dağılımı }\end{array}$ & Erkek & $\begin{array}{l}1 \\
\text { Acem }\end{array}$ & Kadın & $\begin{array}{l}2 \text { Gür- } \\
\text { cü, } 2 \\
\text { Mısırlı }\end{array}$ & Toplam & 5 & & \\
\hline
\end{tabular}

Cinsiyetleri açısından tereke sahiplerine bakıldığında \%84.61'lik bir oranla ezici çoğunluğun erkekler olduğu görülür; nitekim 39 adet tereke kaydının 33'ü erkeklere, 6'sı ise kadınlara aittir. Ancak kadınlara ait tereke kayıtlarının bu düzeyi Kıbrıs'a özgü bir durum değildir. Zira Osmanlı genelinde de mevcut tereke kayıtlarının çoğunun erkeklere ait olduğu ifade edilir. Bu durumun gerekçesi olarak da erkeklerin kadınlara nazaran daha geç yaşta çocuk sahibi olabilmeleri gösterilmektedir. ${ }^{28}$ Mezkûr sonucun ortaya çıkmasında ilgili dönemdeki iktisadî gücün kadın ve erkek cinsleri arasındaki dağılım oranından da kaynaklandığı düşünülebilir. Yukarıdaki sayısal veriler aşağıdaki tabloda gösterilmiştir.

Tablo:2

\begin{tabular}{|l|l|l|l|l|}
\hline Tereke Sayısı & 39 & & & \\
\hline Tereke Sahibi & Erkek & $33(\% 84.61)$ & Kadın & $6(\% 15.39)$ \\
\hline
\end{tabular}

Mevlaların ${ }^{29}$ kadın olduğu tereke kayıtlarının tamamında kölelerin de kadın

\footnotetext{
28 Bozkurt, "Tereke Defterleri ve Tereke Çalışmaları", s. 193; Sabev, "Tereke ve Muhallefat KayıtlarI", s. 264.

29 Cinsiyet ayrımı yapmaksızın köle sahiplerini ifade etmek üzere tercih ettiğimiz bir kavramdır. İslam hukukunda bir terim olarak köle sahibi veya kölesini âzat etmiş olan kimse anlamına gelir. bkz. Erdoğan, Fıkıh ve Hukuk Terimleri Sözlüğü, s. 372.
} 
olduğu gözlenmiştir. Kadın mevlalar genelde 1'er câriyeye sahip olmuş, sadece Bâd-ı Seher isimli bir mevlanın 2 câriyesinin olduğu gözlenmiştir. ${ }^{30}$ Gerek hukukî gerekse sosyolojik olarak Osmanlı Kıbrısı'nda kadınların erkek köle istihdam etmesinde hiçbir mani bulunmamakla ve birçok belge kadınların erkek kölelere sahip olabildiklerini göstermekle beraber, onların daha çok câriye kullanmayı tercih ettikleri ifade edilebilir. Bu da muhtemelen kadınların câriyeleri ev işlerinde hizmetkâr olarak kullanmalarından kaynaklanmıştır. Buna mukabil terekelerinde büyük miktarda tarla, bahçe, hayvan gibi işlenmesi veya kullanılması kuvvet gerektirecek malları olan erkeklerin de umumiyetle erkek kölelere sahip oldukları gözlenmiştir. Ancak erkekler kadınlara nazaran karşı cinsten kölelere çok daha fazla sahip olmuşlardır. Zira incelenen tereke kayıtlarında yer alan 65 kölenin 58'i erkeklerin eli altında olup 35 erkek ve 23 kadından müteşekkildir. Sözü edilen veriler aşağıdaki tabloda gösterilmiştir.

Tablo:3

\begin{tabular}{|l|l|l|l|l|l|l|}
\hline Köle Sayısı & 65 & & & & & \\
\hline $\begin{array}{l}\text { Erkeklerin } \\
\text { Sahibi oldu- } \\
\text { ğu köleler }\end{array}$ & $\begin{array}{l}\text { Erkek } \\
\text { Köle }\end{array}$ & 35 & $\begin{array}{l}\text { Kadın } \\
\text { Köle }\end{array}$ & 23 & Toplam & 58 \\
\hline $\begin{array}{l}\text { Kadınların } \\
\text { sahibi oldu- } \\
\text { ğu köleler }\end{array}$ & $\begin{array}{l}\text { Erkek } \\
\text { Köle }\end{array}$ & 0 & $\begin{array}{l}\text { Kadın } \\
\text { Köle }\end{array}$ & 7 & Toplam & 7 \\
\hline
\end{tabular}

Müntesip oldukları din açısından mevlalara ve kölelere bakıldığında, saray tercümanı olan 1 gayrimüslim mevla ${ }^{31}$ hariç tamamının Müslüman olduğu, isimlerinden ve terekelerinden anlaşılmaktadır. Her ne kadar Osmanlı'da kölelerin genellikle efendilerinin dinine tabi oldukları düşünülse de ${ }^{32}$ incelenen tereke kayıtlarındaki köleler açısından mevzu bu kadar net değildir. Zira tereke kayıtları, zaman zaman kölelerin isimlerini zikretse de bu konuda net bir değerlendirmeye imkân verecek bilgi sunmamıştır. Ancak sadece tereke kayıtları değil de genel olarak Kıbrıs kadı sicillerindeki köleler üzerine yapmış olduğumuz incelemeler, Osmanlı Kıbrısı'ndaki kölelerin kahir ekseriyetinin Müslümanlardan müteşekkil olduğunu ifade etmemize imkân tanımaktadır.

\footnotetext{
30 KŞS (Kıbrıs Şer'iyye Sicilleri)-17-61/102.

31 KŞS-16-213/347. Söz konusu kölenin dinî durumu hakkında terekede bilgi yer almasa da gayrimüslim olduğu düşünülebilir. Zira yasal olarak Osmanlı'da gayrimüslim bir kimse Müslüman köle edinememekteydi. Geniş bilgi için bkz. Erkan, Nevzat, 18. yy'ın İlk Yarısında Üsküdar'da Müslim Gayrimüslim ilişkileri-Şer'iyye Sicilleri ve Müdevvel Kaynaklar Işığında, Basılmamış Doktora Tezi, Marmara Üniversitesi Sosyal Bilimler Enstitüsü, İstanbul, 2012, s. 164.

32 Sak, İzzet, Şer'iyye Sicillerine Göre Sosyal ve Ekonomik Hayatta Köleler 17. ve 18. Yüzyıllar, Basılmamış Doktora Tezi, Selçuk Üniversitesi Sosyal Bilimler Enstitüsü, Konya, 1992, s. 82.
} 
Tereke kayıtlarına göre mevlaların eli altındaki kölelerin oransal dağılımına bakıldığında genelde 1'er köleye sahip olunduğu görülür. Zira 39 adet tereke kaydının 25'inde (\%64.10) sadece 1'er köle yer almaktadır. Nitekim erkeklere ait tereke kayıtlarının 12'sinde 1'er erkek köle, 8'inde ise 1'er câriye vardır. Daha önce de zikredildiği gibi 6 kadın mevlanın terekesinin 5'inde 1'er câriye bulunmaktadır. Binaenaleyh tereke kayıtlarındaki kölelerin genelde 1'er adet olduğu söylenebilir. Bunun dışında sadece 1 erkek ve 1 kadın kölenin yer aldığı tereke kayıtları da dikkate değer bir orandadır. Bunlar 8 adettir ve oran itibariyle \%20.51'e tekabül etmektedir. ${ }^{33}$ Geriye kalan kayıtlarda ise 1 köle, 3 câriye; ${ }^{34}$ 2 köle, 2 câriye; 356 köle 2 câriye; ${ }^{36}$ sadece 2 köle ${ }^{37}$ veya 2 câriye ${ }^{38}$ gibi muhtelif rakamlara da rastlanmaktadır. Yukarıdaki rakamsal bilgiler aşağıdaki tabloda gösterilmiştir.

Tablo:4

\begin{tabular}{|l|l|l|l|}
\hline \multicolumn{2}{|c|}{ Tereke Kayıtlarındaki Köle Sayıları } & \\
\hline 25 Tereke Kaydında & 1'er Köle & $\% 64.10$ & \\
\hline 10 Tereke Kaydında & 2'şer Köle & $\% 25.64$ & \\
\hline 3 Tereke Kaydında & 4'er Köle & $\% 7.69$ & \\
\hline 1 Tereke Kaydında & 8 Köle & $\% 2.56$ & \\
\hline $\begin{array}{l}\text { Toplam 39 Tereke } \\
\text { Kaydı }\end{array}$ & Toplam 65 Köle & & \\
\hline
\end{tabular}

Terekelerde yer alan köleler, bu kayıtlardaki diğer mallar gibi bedelleriyle beraber zikredilmişlerdir. Bu bedellerin belirlenmesi genellikle mahkemece bilirkişi aracılığıyla yapılır ve kalem kalem her mala belli bir değer biçilerek kayda geçirilirdi. Bunun yanı sıra birçok belgede özellikle vârisi olmadan vefat eden kişilerin kölelerinin ve diğer mallarının pazarda açık artırma usulüyle satıldığı ve elde edilen gelirin kalem kalem yazılarak beytülmâle aktarıldığı da gözlenmiştir. ${ }^{39}$ illgili dönemde köle fiyat veya bedellerini etkileyen birçok etkenden bahse-

\footnotetext{
33 Toplamı 39 adet olan tereke kayıtlarına nispetle elde edilen orandır.

34 KSSS-21-251/568.

35 KŞS-18-100/236.

36 KŞS-21-217/501.

37 KŞS-15-221/668; Sadece 4 adet erkek kölenin bulunduğu kayıt için bkz. KŞS-13-1/10.

38 KŞS-17-61/102.

39 Terekelerdeki kölelerin açık artırma usulüyle satıldığı pazar, kimi belgelerde "sûk-ı sultânî" olarak ifade edilmiştir. bkz. KŞS-1b-74/123; KŞS-1b-74/125; KŞS-18-100/236; Söz konusu pazarın, Lefkoșa hayvan pazarına yakın bir konumda olduğu tahmin edilmektedir. bkz. Erdoğru, M. Akif, Kıbrıs'ta Osmanlılar II, Galeri Kültür Yayınları, Lefkoşa, 2009, s. 105; Hayvan pazarının da 12. yüzyılın başlarından beri Lefkoşa Sarayönü (Atatürk) Meydanı'nda kurulduğu belirtilmektedir. bkz. Hatay, Mete,
} 
dilebilse de ${ }^{40}$ terekelerde geçen kölelerin takdir edilen değerlerine bakıldığında önemli oranda bunların kölelerin niteliklerine bağı olarak değişkenlik arz ettiği anlaşılır. Bunun yanı sıra kölelere takdir edilen bedellerde, muhtemeldir ki enflasyonist iktisadî yapının da etkisiyle yıllar içerisinde oldukça değişken bir yapı da ortaya çıkmıştır. Söz konusu yüzyıllarda dünyadaki genel gidiş ve enflasyonist cereyanların etkisiyle para birimi de değişmiştir. Zira Osmanlı'da 1327 ile 1688 yılları arası "akçe devri” olarak adlandırıırken 1688-1879 yılları arası “kuruş-para devri” olarak adlandırılmıştır. Ancak bu değişikliklerin değişen Osmanlı para birimlerinin değer kaybetmesinin önüne geçemediği ifade edilir. ${ }^{41}$ İlgili dönemlere tekabül eden terekelerdeki fiyat birimleri genel olarak bu devirlere göre değişiklik arz etse de zaman zaman farklı para birimlerinin kullanıldığı da olmuştur.

Tereke defterlerine bakılarak bu dönemde kölelere takdir edilen bedeller hakkında net olmasa da genel bir fikir edinilebilir. Nitekim Osmanlı'da kölelerin bedelleri, niteliklerine bağlı olarak değiştiği gibi, bulundukları yere bağlı olarak da değişkenlik arz etmekteydi. ${ }^{42}$ Osmanlı Kıbrısı'na tekabül eden 1571-1688 yılları arasındaki akçe devrinde, içerisinde kölelerin geçtiği 4 adet tereke kaydına bakıldığında -ki bunlar 17. yüzyıla ait içerisinde kölelerin yer aldığı terekelerin tamamını oluşturmaktadır - kölelerin fiyatlarının 3.000 ile 7.000 akçe arasında değiştiği gözlenir. Bu dönemdeki terekelerde erkek ve kadın köleler arasında bedel bakımından belirgin bir farklılık olmadığı gibi kölenin siyah veya beyaz oluşuna göre de belirgin bir fark yoktur. Örneğin siyahî bir köle 5.000 akçe iken ${ }^{43}$ beyaz köle 4.400 akçe; 44 beyaz câriye 6.000 akçe iken ${ }^{45}$ siyahî câriye $7.000^{46}$ veya $3.000^{47}$ akçe olabilmiştir. Yine bu dönemde serbest piyasada alınıp satılan kölelere bakıldığında fiyatların genel olarak bu bantta seyrettiğji48 ancak zaman zaman câriyelerin ${ }^{49}$ ve kölelerin ${ }^{50}$ fiyatının 10.000 akçelere çıkabildiği gözlenmiştir. Köleler arasındaki bu fiyat değişikliğinin onların nitelikle-

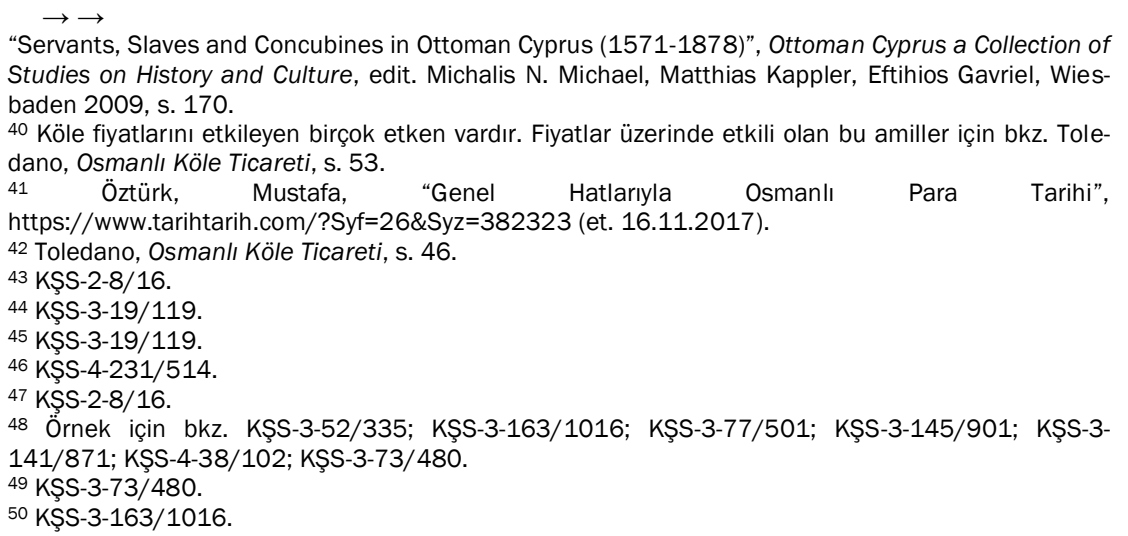


rinden kaynaklandığı düşünülebilir. Ayrıca bu dönem akçe devri olsa da birkaç adet köle satım işleminin kuruş olarak yapıldığı da ayrıca ifade edilmelidir. ${ }^{51}$

İçerisinde kölelerin zikredildiği 39 tereke kaydının 35'i 18. yüzyıla ait olduğundan bu yüzyıldaki köle bedelleri üzerine daha fazla ve açık veri elde edilmiştir. Kuruş-para dönemine tekabül eden bu kayıtlardaki meblağlara bakıldığında, bu dönemde kölelerin bilhassa cinsiyet açısından olmak üzere ırk açısından da bedellerinde belirgin bir değişimin olduğu gözlenir. Bu dönemde terekelerde zikredilen câriyelerin değerleri genel olarak 5.000-8.000 para aralığındayken, bu rakamlar zaman zaman 400 paraya düşüp, ${ }^{52} 16.000^{53}$ paraya kadar da çıkmıştır. Erkeklerin değeri ise genel olarak 2.000 ile 5.000 aralığındayken onlarda da bu rakamlar 500 paraya kadar düşüp54 21.000 paraya kadar çıktığı olmuştur. ${ }^{55}$ Alışveriş piyasasında da genel olarak rakamların terekedeki meblağlara yakın bir düzeyde olduğu söylenebilir. Zira bu meblağlar ya bilirkişiler tarafından belirlenmiş ya da açık artırma usulüyle elde edilmiştir. Görüldüğü üzere bu dönemde kölelerin cinsiyetine göre değerlerinin belirgin bir ölçüde değiştiği, bu değişime göre câriyelerin değerlerinin daha yüksek olduğu açıktır. Zira kadın ve erkek kölelerin gerek ayrı ${ }^{56}$ gerekse beraber bulundukları tereke kayıtlarında ${ }^{57}$ câriyelerin genel olarak daha değerli oldukları görülür. ${ }^{58}$ Hatta bu farklılık cinsler arasında iki katına ${ }^{59}$ ve bazen daha da fazlasına çıkabilmiştir. ${ }^{60}$ Daha önce de ifade edildiği gibi ırk bakımından bu dönemde tereke kayıtlarında ezici çoğunluğun siyahî olduğu gözlenmiş, az da olsa Gürcü ve Acem gibi beyaz ırklara da rastlanmıştır. Belgelerden anlaşıldığı kadarıyla beyaz kölelerin değerleri siyahîlere göre daha yüksektir. Muhtemelen bu dönemde adada beyaz ırklardan köleler ciddi şekilde azaldığı için değerleri artış göstermiştir. ${ }^{61}$ Yukarıda zikredildiği gibi erkek kölelere ya da gulamlara genelde 2.000 ile 5.000 arası değer biçilirken bir tereke kaydında Acem bir gulama 21.000 para değer biçilmiş, ${ }^{62}$ yine bir başka beyaz gulama 8.000 para takdir edilmiştir. ${ }^{63}$ Benzer şe-

\footnotetext{
51 Örnek için bkz. KŞS-3-77/501; KŞS-3-141/871.

52 KSSS-16-120/190.

53 KȘS-11-91/308.

54 KŞS-15-221/668.

55 KŞS-13-1/10.

56 Örnek için bkz. KŞS-20-34/81; KŞS-20-44/109; KŞS-20-19/47; KŞS-20-05/12; KŞS-19139/290; KŞS-19-53/119; KŞS-18-60/129, KŞS-15-221/668.

57 KŞS-3-19/119; KŞS-18-100/236; KŞS-19-71/146; KŞS-20-52/130; KŞS-21-17/70; KŞS-21217/501a; KŞS-21-123/320.

58 Bernard Lewis de Osmanlı toplumunda kölelerin fiyatlarının niteliklerine göre değişkenlik arz ettiğini ve kadın kölelerin genel olarak erkeklerden daha değerli olduklarını ifade eder. bkz. Lewis, Irk ve Kölelik, s. 25.

59 KŞS-21-123/320; KŞS-19-71/146.

60 KŞS-21-217/501a; KŞS-20-52/130.

61 Toledano, Osmanlı Köle Ticareti, s. 53; Söz konusu dönem Kıbrıs'ında beyaz kölelerin değerlerinde zaman içerisinde belirgin bir artış meydana gelmekle beraber Toledano'ya göre beyaz köleler tarihî süreçte genel olarak siyahîlerden daha değerliydiler. bkz. Toledano, Osmanlı Köle Ticareti, s. 5. 62 KŞS-13-1/10.
} 
kilde yine bir terekede beyaz bir Gürcü câriyeye 6.000 para değer biçilmiş olup ${ }^{64}$ bu dönemde beyaz bir câriye çocuğuyla beraber 550 akçeye satılmıştır65 ki bu meblağlar ortalama değerlere göre oldukça yüksektir.

Yukarıda zikredilen köle bedellerinin işlem gördükleri zamanın iktisadî hayatı içerisinde ne kadarlık bir alım gücüne tekabül ettiği merak konusu olabilir. Zira bu bedeller, hem ilgili dönemlerde kölelerin ifade ettiği ekonomik değere hem de onların elde edilebilirliğine ışık tutacaktır. Bunun için söz konusu yüzyıllardaki küçük ve büyükbaş hayvanlara biçilen değerlere ait burada birkaç örnek ve bilgi paylaşılarak köle bedellerinin yaklaşık alım güçlerine dair bir fikir edinilmeye çalışılacaktır. Zira eski zaman dilimlerinde yer alan bazı bedellerin alım gücünün mukayese edilmesinde bu yöntemden faydalanılmaktadır.

Bu dönemdeki tereke kayıtlarının tamamı üzerinde yaptı̆ı̆ımı incelemede buralarda zikredilen hayvanlar içerisinde büyükbaş olarak en fazla öküzün, küçükbaş olarak da koyun ve keçinin zikredildiği tespit edilmiştir. Bu durum özellikle sözü edilen hayvanların o dönemin ekonomisinin önemli bir parçası olduğunu göstermektedir. Zira tereke kayıtlarının dışındaki belgelerde de bu hayvanlar alım satımlara sıklıkla konu olmuştur. Özellikle öküzlerin o dönemin iktisadî hayatında önemli bir yerinin olduğu açıktır. Zira iğdiş edilmiş erkek sığır olan öküzler, tarlaların işlenmesinde, kağnı çekmekte kullanıldığı gibi etinden ve derisinden de yararlanılan, makineleşmenin olmadığı dönemlerde ciddi bir fonksiyon icra eden hayatî bir önemi haiz hayvanlardır. Dolayısıyla bedel mukayesesinde büyükbaş olarak öküz, küçükbaş olarak da kayıtlarda genelde karma bir şekilde beraber zikredilen koyun ve keçi esas alınacak; bu mukayeselere örnek olmak üzere başlıca 2 adet tereke kaydı zikredilecektir.

1018/1610 tarihli bir tereke kaydında beyaz bir câriyeye biçilen değer 6.000 akçe iken aynı tereke kaydında yer alan öküzün değeri 700 akçedir. Yine aynı kayıt beyaz bir kölenin değerinin de 4.400 akçe olduğunu göstermektedir. Dolayısıyla bu belgede, câriye yaklaşık 8.6, erkek köle de 6.28 öküze eş değer bir bedeli ifade etmektedir. 66 Sözü edilen veriler aşağıda gösterilmiştir.

Tablo:5

\begin{tabular}{|l|l|l|l|l|}
\hline $\begin{array}{l}\text { Beyaz Erkek } \\
\text { Köle }\end{array}$ & $\begin{array}{l}4.400 \\
\text { Akçe }\end{array}$ & $\begin{array}{l}\text { Öküz be- } \\
\text { deli }\end{array}$ & 700 Akçe & $\begin{array}{l}1 \text { erkek köle 6.28 öküz } \\
\text { bedelidir. }\end{array}$ \\
\hline $\begin{array}{l}\text { Beyaz Kadın } \\
\text { Köle }\end{array}$ & $\begin{array}{l}6.000 \\
\text { Akçe }\end{array}$ & $\begin{array}{l}\text { Öküz be- } \\
\text { deli }\end{array}$ & 700 Akçe & $\begin{array}{l}1 \text { kadın köle } 8.6 \text { öküz } \\
\text { bedelidir. }\end{array}$ \\
\hline
\end{tabular}

\footnotetext{
63 KŞS-20-159/372.

64 KŞS-20-52/130.

65 KŞS-20-136/324.

66 KŞS-3-19/119.
} 
1143/1730 tarihli bir başka tereke kaydında ise siyahî bir câriyeye 13.000 para değer biçilirken bir çift öküzüne 1.000, bir ineğe ise 800 para değer biçilmiştir. Buradan da câriyenin 13 çift öküzüne veya 16.25 ineğe eş değer bir bedele sahip olduğu görülür. ${ }^{67}$ Aynı belgede 26.200 para değerinde 518 adet koyun ve keçi de bulunmaktadır.68 Dolayısıyla aynı câriye küçükbaş hayvan mukabili olarak yaklaşık 257 adet koyun veya keçiye denk gelmektedir ki bu rakam mezkûr câriyenin oldukça değerli olduğunu göstermektedir. Yukarıdaki rakamsal bilgiler aşağıdaki tabloda gösterilmiştir.

Tablo:6

\begin{tabular}{|l|l|l|l|l|}
\hline $\begin{array}{l}\text { Siyahî Ka- } \\
\text { dın Köle } \\
\text { Para }\end{array}$ & $\begin{array}{l}\text { Çift öküzü } \\
\text { bedeli }\end{array}$ & 1.000 Para & $\begin{array}{l}1 \text { siyahî kadın köle } \\
13 \text { çift öküzü bede- } \\
\text { lidir. }\end{array}$ \\
\hline $\begin{array}{l}\text { Siyahî Ka- } \\
\text { dın Köle } \\
13.000 \\
\text { Para }\end{array}$ & İnek bedeli & 800 Para & $\begin{array}{l}1 \text { siyahî kadın köle } \\
16.25 \text { inek bedeli- } \\
\text { dir. }\end{array}$ \\
\hline $\begin{array}{l}\text { Siyahî Ka- } \\
\text { dın Köle }\end{array}$ & $\begin{array}{l}\text { Para } \\
\text { bedeli }\end{array}$ & $\begin{array}{l}\text { Koyun/keçi } \\
257 \text { kiyahî kadın köle } \\
\text { bedelidir. }\end{array}$ \\
\hline
\end{tabular}

İlgili tereke belgelerinden elde edilen verilerin tamamına yakını 18. yüzyıla ait olduğundan seçilen hayvanların bedellerinin bu yüzyıldaki terekelerde zikredilen değerlerine göz atılması, mukayese için daha sağlıklı bir zemin oluşturacaktır. Bu dönemde kölelerin fiyatlarının mukayese edildiği öküzlerin, cinsine ve vasfına göre fiyatlarının oldukça değişken olduğu ifade edilebilir. ${ }^{69}$ Bunlar kimi zaman 250 para değerinde olabildiği gibi70 kimi zaman da 1.500 paraya ulaşabilmektedir. ${ }^{71}$ Fakat bunların ortalama 500-1.000 para aralığında olduğu söylenebilir. ${ }^{72}$ Küçükbaş hayvanlardan koyun ve keçilerin bedelleri ise zaman zaman hayvan başına 10 paraya düşüp ${ }^{73} 100$ paraya çıkmış olsa da ${ }^{74}$ ortalama

\footnotetext{
67 KŞS-13-222/702.

68 Her bir koyun/keçi 50.57 Paraya tekabül etmektedir.

69 Örnek için bkz. KŞS-18-17/39.

70 KSSS-18-23/311.

71 KȘS-13-223/703.

72 Örnek için bkz. KŞS-11-93/311; KŞS-13-22/702; KŞS-16-122/194; KŞS-19-71/146; KŞS-20$33 / 77$.

73 KŞS-11-4/10.

74 KŞS-13-223/704.
} 
50 para civarında seyretmiştir. ${ }^{75}$ 18. yüzyıldaki terekelerde geçen 20 erkek köIenin ${ }^{76}$ bedellerinin aritmetik ortalaması yaklaşık 6.330 para yapmaktadır. Öküz bedeli olarak 750 para ortalama bir rakam olarak kabul edilirse bu dönemde bir erkek kölenin 8.44 öküz bedeli olduğu, koyun veya keçi bedeli olan 50 para üzerinden de 126.6 küçükbaş hayvana denk geldiği anlaşılmaktadır. Yine bu dönemdeki 16 câriyenin ${ }^{77}$ bedellerinin aritmetik ortalaması yaklaşık 6.530 paradır. Bu da aynı hesaba göre 8.70 öküze veya 130.6 koyun/keçiye tekabül etmektedir. Yaklaşık yüz yıllık bir zaman diliminde köle ve mezkûr hayvan fiyatlarının birbirleriyle doğru orantılı olmayacak biçimde dalgalanma göstermesinin ve buna bağlı olarak zaman içerisinde değişkenlik arz etmesinin kaçınılmaz bir durum olduğunu göz önünde bulundurarak, burada belirtilen bedellere ortalama değerler olarak bakılmalıdır. ${ }^{78}$ Zira başlangıçta da belirtildiği gibi söz konusu kölelerin bedellerinin adı geçen büyükbaş ve küçükbaş hayvanlarla mukayese edilmesindeki gaye, kölelerin bedellerinin alım gücü hakkında bir fikir edinmedir. Görülen odur ki söz konusu dönemde köle sahibi olmanın bedeli, yukarıda zikredilen ve pek de küçümsenmeyecek meblağlara tekabül etmiştir. Sözü edilen veriler aşağıdaki tabloda gösterilmiştir.

Tablo:7

\begin{tabular}{|l|l|l|l|l|}
\hline $\begin{array}{l}\text { Erkek } \\
\text { Köle Be- } \\
\text { del Ort. }\end{array}$ & $\begin{array}{l}6.330 \\
\text { Para }\end{array}$ & $\begin{array}{l}\text { Öküz bedel } \\
\text { ort. }\end{array}$ & $\begin{array}{l}750 \text { Pa- } \\
\text { ra }\end{array}$ & $\begin{array}{l}1 \text { erkek köle 8.44 öküz be- } \\
\text { delidir. }\end{array}$ \\
\hline $\begin{array}{l}\text { Erkek } \\
\text { Köle Be- } \\
\text { del Ort. }\end{array}$ & $\begin{array}{l}6.330 \\
\text { Para }\end{array}$ & $\begin{array}{l}\text { Koyun/keçi } \\
\text { bedel ort. }\end{array}$ & 50 Para & $\begin{array}{l}1 \text { erkek köle 126.6 ko- } \\
\text { yun/keçi bedelidir. }\end{array}$ \\
\hline $\begin{array}{l}\text { Kadın } \\
\text { Köle Be- } \\
\text { del Ort. }\end{array}$ & $\begin{array}{l}6.530 \\
\text { Para }\end{array}$ & $\begin{array}{l}\text { Öküz bedel } \\
\text { ort. }\end{array}$ & $\begin{array}{l}750 ~ P a-~ \\
\text { ra }\end{array}$ & $\begin{array}{l}1 \text { kadın köle } 8.7 \text { öküz be- } \\
\text { delidir. }\end{array}$ \\
\hline $\begin{array}{l}\text { Kadın } \\
\text { Köle Be- } \\
\text { del Ort. }\end{array}$ & $\begin{array}{l}6.530 \\
\text { Para }\end{array}$ & $\begin{array}{l}\text { Koyun/keçi } \\
\text { bedel ort. }\end{array}$ & 50 Para & $\begin{array}{l}1 \text { kadın köle 130.6 ko- } \\
\text { yun/keçi bedelidir. }\end{array}$ \\
\hline
\end{tabular}

75 KŞS-19-71/146; KŞS-9-23/65; KŞS-11-91/308; KŞS-13-222/702; KŞS-13-1/10; KŞS-1823/50.

${ }^{76}$ Kendilerine müstakil olarak ve para cinsinden değer biçilen erkek köleler.

77 Kendilerine müstakil olarak ve para cinsinden değer biçilen kadın köleler.

78 Osmanlı'da köle fiyatlarına ve köle ticaretinin diğer ekonomik yönlerine dair "kesin bilgilerin" birçok sebebe bağlı olarak net bir şekilde verilemeyeceğini belirten Toledano, pazar fiyatlarının istikrarsızlığı, kölelerin kişisel özelliklerinin değerlerinin belirlenmesindeki önemi gibi sebeplerin kesin ve net sonuçlara ulaşmayı engellediğini ifade etmektedir. bkz. Toledano, Osmanlı Köle Ticareti, s. 52. 


\section{Değerlendirme}

Bu noktada, çalışmanın muhtelif yerlerinde zikredilen bazı mühim verilerin özetlenmesinde ve ulaşılan sonuçların genel bir şekilde değerlendirilmesinde fayda vardır. İnceleme dönemimiz olan 17. ve 18. (H. 12-13) yüzyıl Kıbrıs kadı sicil defterlerinde 287 adet tereke kaydı tespit edilmiş olup bunların sadece 39 adedinde köle yer almıştır. Dolayısıyla döneme ait tereke kayıtlarının sadece \%13.58'inde köle bulunduğu ifade edilebilir. Bu durum toplumun oldukça sınırlı bir kesiminin köle sahibi olduğuna dair önemli bir göstergedir. Zira incelenen tereke kayıtlarındaki mal varlıklarının genel düzeyi göz önünde bulundurulduğunda bu oranın gerçekte çok daha düşük olduğu düşünülebilir. Öyle ki ilgili dönem tereke kayıtlarının genelde varlıklı insanlara ait oldukları dikkat çekmektedir. Dolayısıyla en azından fakir ve orta halli denebilecek kimselerin terekelerinin zenginler kadar mahkeme kayıtlarına yansımamış olması muhtemeldir. Zira mahkemece terekelerden tahsil edilen "resm-i kısmeti", yani tereke düzenleme ücretini vermemek için az miktardaki malı tevarüs eden fakir ve orta halli mirasçıların taksimat amacıyla mahkemeye müracaattan içtinap edebilecekleri de göz önünde bulundurulmalıdır.

İlgili terekelerde toplam 65 köle zikredilmiş olup bunların 35'inin erkek, 30'unun da kadın olduğu gözlenmiştir. Dolayısıyla cinsiyetler arasında dengeli bir dağılım söz konusudur. Ancak erkek ve kadın kölelerin ezici çoğunluğu siyahîdir. Zira 65 adet kölenin 49'u siyahî olup, sadece 8'i beyazdır. Geriye kalan diğer 8 kölenin de ırkından veya renginden bahsedilmemiştir. Binaenaleyh terekelerde geçen kölelerin en az \%75.38'inin siyahî olduğu ifade edilebilir.

Cinsiyetleri açısından tereke sahiplerine bakıldığında \%85'lik bir oranla ezici çoğunluğun erkekler olduğu görülmüştür. Zira 39 adet tereke kaydının 33'ü erkeklere, 6'sı kadınlara aittir. Kadınlara ait tereke kayıtlarının sayısındaki bu düşüklük, Kıbrıs'a özgü bir durum olmayıp Osmanlı genelinde de gözlenen umumi bir olgudur. Bu durumun ortaya çıkmasında genel olarak erkeklerin kadınlara nazaran daha geç yaşta çocuk sahibi olabilmelerinin etkili olduğu ifade edilir. Bununla beraber ilgili dönemdeki iktisadî gücün kadın ve erkek cinsleri arasındaki dağılımının da bu sonucun ortaya çıkmasında önemli bir payının olduğu düşünülebilir.

Köle sahiplerinin kadın olduğu tereke kayıtlarının tamamında kölelerin de kadın olduğu gözlenmiştir. Kadın mevlaların terekelerinde genelde 1'er câriye bulunmuştur. Gerek hukukî gerekse sosyolojik açıdan Osmanlı Kıbrısı'nda kadınların erkek köle istihdam etmelerinde herhangi bir mani bulunmamaktadır. Zira tereke kayıtlarının dışındaki birçok belge kadınların erkek kölelere sahip olabildiklerini açık bir şekilde göstermektedir. Ancak onların daha çok câriye 
kullanmayı tercih ettikleri ifade edilebilir. Bunun da kadınların câriyeleri ev işlerinde hizmetkâr olarak kullanmalarından kaynaklanmış olması muhtemeldir. Buna mukabil terekelerinde büyük miktarda tarla, bahçe, hayvan gibi işlenmesi veya kullanıması kuvvet gerektirecek malları olan erkeklerin de genelde erkek kölelere sahip oldukları gözlenmiştir. Ancak erkekler kadınlara nispetle karşı cinsten kölelere çok daha büyük oranda sahip olmuşlardır. Zira 65 kölenin kadınların elinde olan 7'si hariç 58 adedi erkeklerin eli altındadır. Bu da 35 erkek ve 23 kadın köleye tekabül etmektedir.

Kadın ve erkek mevlaların terekelerinde genelde 1'er köle bulunmuştur. Nitekim 39 adet tereke kaydının 25'inde (\%64.10) sadece 1'er köle yer almıştır. Erkeklere ait tereke kayıtlarının 12'sinde 1'er erkek köle, 8'inde ise 1'er câriye mevcuttur. Yukarıda zikredildiği gibi kadın mevlaların terekelerinin de biri hariç tamamında 1'er câriye vardır. Bunların dışında sadece 1 erkek ve 1 kadın kölenin yer aldığı tereke kayıtları da 8 adettir ve oran itibariyle \%20.51'e tekabül etmektedir. Geriye kalan kayıtlarda ise 1 köle 3 câriye; 2 köle 2 câriye; 6 köle 2 câriye; sadece 2 köle veya 2 câriye gibi muhtelif rakamlar da bulunmaktadır.

Osmanlı'da kölelerin bedelleri, niteliklerine bağlı olarak değiştiği gibi, bulundukları yere bağlı olarak da değişkenlik arz etmiştir. Kıbrıs tereke defterlerinde kölelerin bedellerinin yer alması, onlara takdir edilen meblağlar hakkında bizlere genel bir bilgi vermektedir. Osmanlı Kıbrısı'nda 1571-1688 yılları arasındaki akçe devrindeki tereke kayıtları, bu dönemde köle fiyatlarının 3.000 ile 7.000 akçe arasında değiştiğini göstermiştir. Bu dönemdeki terekelerde erkek ve kadın köleler arasında bedel bakımından belirgin bir farklıığa rastlanmadığı gibi kölenin siyah veya beyaz oluşuna göre de kayda değer bir fark gözlenmemiştir. Ancak tereke kayıtlarında bu döneme ait yeterli zenginlikte veri bulunmadığı için net yargılardan kaçınmakta fayda vardır.

İçerisinde kölelerin yer aldığı 39 tereke kaydının 35’i 18. yüzyıla ait olduğundan, bu yüzyıldaki köle bedelleri hakkında daha zengin ve açık veriler elde edilmiştir. Kuruş-para dönemine tekabül eden bu kayıtlardaki meblağlara bakıldığında bu dönemde kölelerin cinsiyet ve ırk açısından bedellerinde belirgin bir değişimin olduğu söylenebilir. Bu dönemde terekelerde zikredilen câriyelerin takdir edilen değerleri genel olarak 5.000 ile 8.000 para aralığındayken bu rakamlar zaman zaman 400 paraya düşüp 16.000 paraya kadar da çıkmıştır. Erkeklerde ise bu rakamlar genel olarak 2.000 ile 5.000 aralığındayken, onlarda da bu meblağlar 500 paraya kadar düşüp 21.000 paraya kadar çıktığı olmuştur. Alışveriş piyasasında da durumun genel olarak terekedeki meblağlara yakın bir düzeyde olduğu söylenebilir. 
Görüldüğü üzere bu dönemde kölelerin cinsiyetine göre değerlerinin belirgin bir ölçüde değiştiği, câriyelerin değerlerinin genel olarak daha yüksek olduğu açıktır. Hatta takdir edilen değerlerdeki bu yükseklik iki katına ve bazen daha da fazlasına çıkabilmiştir. Yukarıda zikredildiği gibi ırk bakımından bu dönemde terekelerde ezici çoğunluk siyahîlere aittir. Fakat az da olsa Gürcü ve Acem gibi beyaz ırklara da rastlanmıştır. Anlaşılan o ki bu dönemde Osmanlı genelinde olduğu gibi beyaz kölelerin değerleri siyahîlere göre daha yüksektir. Muhtemelen zamanla adada beyaz ırklardan köleler ciddi bir azalım gösterdiği için değerleri artmıştır.

Yukarıda zikredilen köle bedellerinin işlem gördükleri zamanın iktisadî hayatı içerisinde tekabül ettikleri alım gücü hakkında fikir edinebilmek için ilgili dönemdeki bazı küçük ve büyükbaş hayvanlara biçilen değerlere bakılmıştır. İlgili terekelerden elde edilen verilerin tamamına yakını 18. yüzyıla ait olduğundan seçilen hayvanların, bu yüzyıldaki terekelerde zikredilen değerlerine göz atılması mukayese için daha sağlıklı bir zemin oluşturmuştur. Bu dönemde kölelerin fiyatlarını mukayese ettiğimiz öküzlerin ortalama fiyatlarının 500 ile 1.000 para aralığında olduğunu söyleyebiliriz. Bu dönemde küçükbaş hayvanlardan koyun ve keçilerin bedelleri de ortalama 50 para civarındadır. 18. yüzyıl Kıbrıs terekelerinde geçen 20 erkek kölenin bedellerinin aritmetik ortalaması yaklaşık 6.330 paradır. Öküz bedeli olarak 750 para ortalama bir rakam olarak kabul edildiğinde bu dönemde bir erkek kölenin 8.44 öküz bedeli olduğu, koyun veya keçi bedeli olan 50 para üzerinden de 126.6 küçükbaş hayvana denk geldiği söylenebilir. Yine bu dönemdeki 16 câriyenin bedellerinin aritmetik ortalaması yaklaşık 6.530 paradır ve bu da aynı hesaba göre 8.7 öküze veya 130.6 koyun/keçiye tekabül etmektedir. Tüm bu meblağlar söz konusu dönemde vasat bir köle sahibi olmanın -genel olarak- azımsanmayacak bir maddi gücü gerektirdiğine açık bir şekilde işaret etmektedir.

\section{Sonuç}

Tereke kayıtları üzerine yapılan bu araştırma, ilgili dönem Kıbrıs'ındaki kölelere dair zengin veriler sunmuştur. Terekelerde yer alan kölelerin sayısı, cinsiyeti, ırkı ve değeri gibi birçok hususta aydınlatıcı bilgiler edinilmiş ve bu hususlara dair detaylı bilgiler yeri geldikçe paylaşılmıştır. Bunlara ilaveten ve sonuç mahiyetinde denebilir ki incelenen döneme ait tereke kayıtları, Osmanlı dönemi Kıbrıs'ının adaya hâkim olan önceki devletler gibi köleci bir yapıda olmadığını açık bir şekilde ortaya koymuştur. Zira ilgili dönemin tüm tereke kayıtlarından müteşekkil olan 287 adet tereke kaydının sadece 39'unda kölelerin varlığı tespit edilmiş ve bu da oran olarak \%13.58 gibi oldukça düşük bir rakama tekabül etmiştir. Haddizatında toplumun köle sahibi olma oranının bu rakamdan çok 
daha düşük olduğu kuvvetle muhtemeldir. Zira incelenen tereke kayıtlarının genelde varlıkı kişilere ait olduğu; özellikle ardında bıraktığı mal varlığı pek fazla olmayan veya öldükten sonra muhtelif sebeplerle mal varlığı mahkeme kayıtlarına yansımayan birçok kişinin tereke kaydının tutulmadığı göz önünde bulundurulmalıdır.

Incelenen tereke kayıtları toplumun hemen her kesiminden çok sayıda kişinin geride bıraktığı mal varlığını objektif biçimde yansıtması bakımından toplum içerisindeki kölelerin nitelik ve niceliğine dair oldukça mevsuk bilgiler sunmuştur. Belge temelli bu bilgilerden istifade edilerek kölelik kurumu üzerine yapılacak araştırmalar büyük bir önemi haizdir. Nitekim özel olarak Osmanlı Kıbrısı'ndaki kölelik müessesesinin, genel olarak da Kıbrıs'ın sosyal tarihinin aydınlatılması noktasında bu çalışmada paylaşılan detaylı veriler de bu alanda yapılacak yeni araştırmalara katkıda bulunacaktır.

\section{Kaynaklar}

» Kıbris Şer'iyye Sicilleri, 1B, 2, 3, 4, 5, 6, 7, 8, 9, 10, 11, 12, 13, 14, 15, 16, 17, 18, 19, 20, 21, 22 numaralı defterler.

» Akgündüz, Ahmed, İslâm Hukukunda Kölelik-Câriyelik Müessesesi ve Osmanlı'da Harem, Osmanlı Araştırmaları Vakfı, i̇stanbul, 2006.

» Alvân, Abdullah Nâsıh, Nizâmu'r-rıq fi't-lislâm, Dâru's-selâm, yk., 2004.

» Aydın, M. Âkif, Türk Hukuk Tarihi, 5. Baskı, Hars Yay., İstanbul, 2005.

" Bakırezer, Güven, “Antik Yunan Düşüncesinde Kölelik”, Ankara Üniversitesi SBF Dergisi, 63/1, (2008), ss. 17-54.

" Bilmen, Ömer Nasuhi, Hukukı İslâmiyye ve Istılahatı Fıkhıyye Kamusu, I-VIII, Bilmen Yayınevi, istanbul, ty.

" Bozkurt, Fatih, "Osmanlı Dönemi Tereke Defterleri ve Tereke Çalışmaları", Türkiye Araştırmaları Literatür Dergisi (TALiD), 11/22, (2013), ss. 193-229.

» Buhârî, Ebû Abdullah Muhammed b. İsmail, Sahihü'l-Buhârî, el-Mektebetü'-Isılâmiyye, ìstanbul, 1979.

» Câhız, Ebû Osman Amr b. Bahr, el-Beyân ve't-tebyîn, Neşr. Muhammed Harûn Abdüsselam, Kahire, 1418/1997.

" Ebû Dâvûd, Süleyman b. Eş'as b. İshak el-Ezdî es-Sicistanî, Sünenu Ebî Dâvûd, thk. Muhammed Muhyiddin Abdülhamid, Dârü'l-Fikr, Beyrut, ty.

" Ekinci, Ekrem Buğra, Osmanlı Hukuku, Arı Sanat Yay., İstanbul, 2008.

» Erdoğan, Mehmet, Fıkıh ve Hukuk Terimleri Sözlüğü, Ensar Neşriyat, İstanbul, 2005.

》Erdoğru, M. Akif, Kıbrıs'ta Osmanlılar II, Galeri Kültür Yayınları, Lefkoşa, 2009.

" Ergene, Boğaç A., "Costs of Court Usage in Seventeenth and Eighteenth Century Ottoman Anatolia: Court Fees as Recorded in Estate Inventories", Journal of the Economic and Social History of the Orient, 45/1, (2002), ss. 20-39.

" Erkan, Nevzat, 18. yy'ın Illk Yarııında Üsküdar'da Müslim-Gayrimüslim ilişskileri-Şer'iyye Sicilleri ve Müdevvel Kaynaklar Işı̆̆ında, Basılmamış Doktora Tezi, Marmara Üniversitesi Sosyal Bilimler Enstitüsü, İstanbul, 2012.

» Fendoğlu, Hasan Tahsin, İslâm ve Osmanlı Hukukunda Kölelik ve Câriyelik, Beyan Yayınları, ìstanbul, 1996.

» Hamîdullah, Muhammed-Aydın, Mehmet Âkif, "Köle”, Türkiye Diyanet Vakfı i̇sâm Ansikıopedisi (DiA), XXVI, Ankara, 2002, ss. 237-246.

" Hamidullah, Muhammed, İslâm'da Devlet ídaresi, Çev. Hamdi Aktaş, Beyan Yay., İstanbul, 1998.

» Hatalmış, Ali, Erken Dönem İslam Tarihinde Kölelik ve Câriyelik (Hz. Peygamber Döneminden Emevîlerin Sonuna Kadar), Basılmamış Doktora Tezi, Ankara Üniversitesi

》 Sosyal Bilimler Enstitüsü, Ankara, 2012.

” Harekât, ibrahim, es-Siyâsetu ve'l-mucteme'u fi'l-asri'l-Emevî, Rabat, 1410/1990.

" Hatay, Mete, "Servants, Slaves and Concubines in Ottoman Cyprus (1571-1878)" Ottoman 
Cyprus a Collection of Studies on History and Culture, edit. Michalis N. Michael, Matthias Kappler, Eftihios Gavriel, Wiesbaden, 2009, ss. 161-180.

» Hudari, Muhammed, İslam Hukuku Tarihi, Çev. Haydar Hatiboğlu, Kahraman Yayınları, İstanbul, 1987.

» İnalcık, Halil, “XVI. Asır Türkiye'nin İktisadî ve İctimaî Kaynakları”, İstanbul Üniversitesi İktisat Fakültesi Mecmuası, 15/1-4, (1954), ss. 51-67.

" ----, "Osmanlı Tarihi Hakkında Mühim Bir Kaynak”, Ankara Üniversitesi Dil ve TarihCoğrafya Fakültesi Dergisi, 1/1, (1943), ss. 89-96.

" Karataş, Ali İhsan, “Tereke Kayıtlarına Göre XVI. Yüzyılda Bursa'da İnsan-Kitap İlişkisi”, Uludağ Üniversitesi Illahiyat Fakültesi Dergisi, 8/8, (1999), ss. 317-328.

» Lewis, Bernard, Ortadoğu'da Irk ve Kölelik, Çev. Enver Gürsel, Truva Yayınları, İstanbul, 2006.

" Martal, Abdullah, “Köleliğin Yeni Boyutları: Çağdaş Kölelik ve Çalışma Hakkı”, Türkiye'de insan Hakları Konferansı, 7-9 Aralık 1998 Ankara, Türkiye ve Orta Doğu Amme İdaresi Enstitüsü, Ankara, 1998, ss. 369-375.

" Müslim, Ebû'l-Huseyn el-Kuşeyrî en-Nîsâburî Müslim b. el-Haccâc, Sahihi Müslim, thk. Muhammed Fuâd Abdülbâkî, Dâru ihyai't-türasi'I-Arabî, Beyrut, 1956.

" Özcan, Tahsin, "Muhallefât”, Türkiye Diyanet Vakfı İslâm Ansiklopedisi (DiA), XXX, İstanbul, 2005, ss. 406-407.

» Özdemir, Mehmet Nadir, İslam'ın IIlk Döneminde Kölelik Abbasilerin illk Yüzyılı, Gökkubbe Yay., İstanbul, 2006.

» Özel, Ahmet, İslam Devletler Hukukunda Savaş Esirleri, Türkiye Diyanet Vakfı Yay., Ankara, 1996.

» Öztürk, Mustafa, “Genel Hatlarıla Osmanlı Para Tarihi”, https://www.tarihtarih.com/?Syf=26\&Syz=382323 (et. 16.11.2017).

» Pakalın, Mehmet Zeki, Osmanlı Tarih Deyimleri ve Terimleri Sözlüğü, Milli Eğitim Basımevi, I-III, İstanbul, 1983.

»Sabev, Orlin, "Osmanlı Toplumsal Tarihi İçin Değerli Kaynak Teşkil Eden Tereke ve Muhallefat Kayıtları", Osmanlı Coğrafyası Kültürel Arşiv Mirasının Yönetimi ve Tapu Arşivlerinin Rolü Uluslararası Kongresi, Bildiriler, I, 21-23 Kasım 2012 istanbul, ss. 259-272.

»Sak, İzzet, Şer'iyye Sicillerine Göre Sosyal ve Ekonomik Hayatta Köleler 17. ve 18. Yüzyıllar, Basılmamıș Doktora Tezi, Selçuk Üniversitesi Sosyal Bilimler Enstitüsü, Konya, 1992.

" Sarıçam, İbrahim-Erşahin, Seyfettin, İslam Medeniyeti Tarihi, Türkiye Diyanet Vakfı Yayınları, Ankara, 2017.

» Sertoğlu, Midhat, Osmanlı Tarih Lügatı, Kurtuba Kitap, İstanbul, 2015.

" Tirmizî, Ebû İsa Muhammed b. İsa b. Sevre es-Sülemî, Sünenü't-Tirmizî, tahkik ve şerh İbrâhim Atve İvaz, Mustafa el-Bâbî el-Halebî, Kahire, 1975.

» Toledano, Ehud R., Suskun ve Yokmuşçasına İslâm Ortadoğusu'nda Kölelik Bağları, İstanbul Bilgi Üniversitesi Yayınları, İstanbul, 2010.

"----, Osmanlı Köle Ticareti 1840-1890, Tarih Vakfı Yurt Yayınları, İstanbul, 2000.

" Trevor-Roper, Hugh Redwald, The Past and the Present History and Sociology, the London School of Economics and Political Science, Londra, 1969.

» Urfe, Muhammed, “Lâ ta 'rîfu'l-insâniyye hadâratü kâvameti'r-rıkki ke'l-İslâm”, Mecelletü'lEzher, Kahire, (1954), 25/2, ss. 201-298. 